\title{
Role of Intravenous Lidocaine Infusion in the Treatment of Peripheral Neuropathy
}

\author{
Harshit Gupta, BSA ${ }^{1}$, Anjana Patel, BS², Zahaan Eswani, BS ${ }^{3}$, Peyton Moore, BS³, Mattie Steib, BS ${ }^{3}$, Christopher Lee, MD \\ ${ }^{4}$, , Alan D. Kaye, MD, Ph.D. ${ }^{5}$ \\ 1 David Geffen School of Medicine, University of California Los Angeles, ${ }^{2}$ School of Medicine, Georgetown University, ${ }^{3}$ School of Medicine, Louisiana \\ State University Health Science Center Shreveport, ${ }^{4}$ Department of Internal Medicine, Creighton University School of Medicine-Phoenix Regional \\ Campus, 5 Department of Anesthesiology, Louisiana State University Health Science Center Shreveport \\ Keywords: neuropathic pain, peripheral neuropathy, lidocaine \\ https://doi.org/10.52965/001c.25567
}

\section{Orthopedic Reviews}

Vol. 13, Issue 1, 2021

\section{Purpose of Review}

This is a comprehensive review of the literature regarding intravenous lidocaine infusion to treat peripheral neuropathy. The clinical symptoms of peripheral neuropathy occur on a broad spectrum and stem from many etiologies resulting in complex treatment approaches. This review presents the background, evidence, and indications for the use of intravenous lidocaine infusions as a treatment option for this condition.

\section{Recent Findings}

The clinical range of peripheral neuropathy symptoms includes pain, numbness, muscle weakness, paresthesia, balance difficulty, and autonomic dysfunction. However, severe neuropathic pain remains one of the most debilitating symptoms that significantly affects the quality of life. Current treatment options include antidepressants, anticonvulsants, and, in some cases, opiates, but these are often ineffective, creating the need for other therapeutic approaches.

The pathophysiology of neuropathic pain involves sodium channels which create abnormal pain responses. Intravenous lidocaine primarily functions by inhibiting membrane sodium channels which desensitize peripheral nociceptors, thus creating an analgesic effect. The research in using intravenous lidocaine for neuropathic pain is not fully complete and requires further evaluation.

\section{Summary}

Peripheral neuropathy is a manifestation commonly resulting from diabetes, alcohol abuse, vitamin deficiencies, and chemotherapy, among other causes. One of the most significant complications is neuropathic pain which is often resistant to multi-modal therapeutic regimens. Intravenous lidocaine infusions are a newer treatment option for neuropathic pain, which have additional anti-inflammatory effects with a minimal side effect profile. Studies have concluded it effectively treats neuropathic pain for weeks after administration, but results are variable depending on specific procedures. Further research, including additional direct comparison studies, should be conducted to fully evaluate this drug's usefulness.

\section{INTRODUCTION}

Peripheral neuropathy is a condition that stems from a wide range of etiologies. It is experienced by millions of Americans worldwide and is increasing in prevalence each year. ${ }^{1}$ Neuropathy is rarely a stand-alone disease and is usually

\footnotetext{
a Corresponding author:

Christopher Lee, MD

St. Joseph Hospital \& Medical Center

Department of Internal Medicine

500 West Thomas Rd

Phoenix, AZ 85013

Chrislee0621@gmail.com
} 
a part of a systemic process that results in injury to peripheral nerve components like axons or myelin sheaths. Metabolic diseases like diabetes or uremia, inflammatory diseases (sarcoidosis), autoimmune diseases (lupus, rheumatoid arthritis), infections (HIV, HCV), injuries (burns, direct trauma), drug-induced toxicity from chemotherapy or antiretrovirals, rare genetic diseases such as Charcot-Marie-Tooth (CMT), and many other etiologies can result in the defects that are found in peripheral neuropathy. ${ }^{2}$

While the etiologies are numerous, the pathophysiology converges on several common mechanisms: metabolic dysregulation, covalent modification of proteins, organelle dysfunction, ROS/RNS production, altered intracellular and inflammatory signaling, axonal transport defects, and ion channel dysfunction. ${ }^{3}$ Research on this topic is still ongoing as mechanisms continue to be discovered and understood.

Peripheral neuropathy can occur in different patterns; it can affect one nerve or multiple nerves, be symmetric or asymmetric, and be sensory, motor, sensorimotor, or autonomic. ${ }^{4}$ Peripheral neuropathy presents with different symptoms depending on which types of nerves are damaged and the severity of this damage. The most common cause of peripheral neuropathy is diabetes, which presents as a distal symmetric polyneuropathy. ${ }^{4-6}$

Peripheral neuropathy can be asymptomatic or mild but can also cause pain, numbness, paresthesia, difficulty balancing, muscle weakness, autonomic dysfunction, and many other symptoms. ${ }^{6}$ Complications of peripheral neuropathy include severe neuropathic pain, ulcer formation, gangrene, amputation, injuries, falls, and difficulties performing daily living activities. ${ }^{6}$ Neuropathic pain is the most debilitating symptom of peripheral neuropathy. Higher pain levels can lead to reduced physical activity, trouble sleeping, and mental health issues like depression and anxiety. ${ }^{7}$ These issues correlate with overall poorer quality of life in those with significant symptoms. ${ }^{7}$

Peripheral neuropathy is associated with greater morbidity and mortality in those with diabetes. ${ }^{8}$ Early detection of peripheral neuropathy through screening and diagnostic testing is extremely important in decreasing morbidity and preventing a decline in quality of life. ${ }^{7}$ These tests include nerve conduction studies, neuropathy disability score, skin biopsy, quantitative sensory testing, and corneal confocal microscopy. ${ }^{8,9}$ With such a high prevalence of peripheral neuropathy and such varying etiologies, research on peripheral neuropathy treatment is critical, especially since it can improve the quality of life in people suffering from the potentially disabling symptoms of peripheral neuropathy.

\section{PERIPHERAL NEUROPATHY EPIDEMIOLOGY}

Although recent epidemiologic studies and data on peripheral neuropathy prevalence are lacking, older studies show that this is an increasingly widespread condition, especially in middle-aged and elderly populations. A study from 2006 claims that of the United States population, $14.8 \%$ of people aged 40 and older have some form of peripheral neuropathy. ${ }^{10}$ Diabetes accounts for around half of neuropathy cases. ${ }^{5}$

When looking at the statistics in the diabetic population, studies suggest that up to one-half of diabetic people will develop peripheral neuropathy in their lifetime. According to the CDC, 34.2 million people in the US currently have diabetes (10.5\% of the US population). ${ }^{11,12}$ On the report of Abbott, Malik, et al., about one-third of patients with diabetic peripheral neuropathy will develop neuropathic pain, which is considered to be the most debilitating symptom of peripheral neuropathy. ${ }^{13}$

It has also been reported that chemotherapy-induced peripheral neuropathy (CIPN) occurs in about $30-40 \%$ of patients taking neurotoxic chemotherapeutics. ${ }^{14}$ Scientists believe that the prevalence of peripheral neuropathy is underestimated and will continue to increase with the increasing prevalence of cancer survival, diabetes, obesity, and metabolic syndrome. ${ }^{1}$ The remaining studies performed on peripheral neuropathy have varying results due to inconsistencies between different etiologies, types of peripheral neuropathy, and populations examined. ${ }^{8}$

\section{PERIPHERAL NEUROPATHY RISK FACTORS AND PATHOPHYSIOLOGY}

Risk factors for developing peripheral neuropathy include but are not limited to diabetes, alcohol abuse, vitamin deficiencies, certain infections, exposure to toxins, treatment with neurotoxic chemotherapeutics or antiretrovirals, a family history of neuropathy, or vascular problems that could cause ischemic damage to nerves. ${ }^{9,15}$

The pathophysiology behind peripheral neuropathy is often multifactorial. Still, most mechanisms fall into the main categories of metabolic dysregulation, covalent modification of proteins, organelle dysfunction and ROS/RNS production, altered intracellular and inflammatory signaling, axonal transport defects, and channelopathies. ${ }^{3}$ Some systemic illnesses can dysregulate metabolic pathways, and the end products of this altered metabolism are often damaging for nerves. For example, hyperglycemia due to diabetes can cause the buildup of damaging reactive intermediates such as sorbitol and other polyols, which disrupt the axonal membrane, reduce a nerve's ability to propagate an action potential, and/or impair regeneration following axonal injury. ${ }^{3} \mathrm{NADPH}$ depletion due to increased glucose levels also leaves a nerve cell more susceptible to oxidant damage and eventual apoptosis. ${ }^{3}$

Some disease states can promote the covalent modification of proteins. Hyperglycemia is an example of this as well; it can lead to the formation of advanced glycation end products (AGEs) through nonenzymatic glycoxidation. ${ }^{16}$ AGEs can alter collagen, affecting blood vessels and increasing a nerve's risk of experiencing hypoxia-induced damage. Modification of laminin, an essential protein for proper development and health of Schwan cells and neurons, by AGEs can limit peripheral nerve recovery after injury. AGEs can also damage DNA by modifying bases and producing double-strand breaks. Similar DNA damage is also caused by platinum chemotherapeutics, which tend to induce apoptosis in sensory neurons, leading to CIPN. ${ }^{14,17}$

Alterations of intracellular and inflammatory signaling pathways can leave nerves susceptible to damage. AGE (RAGE) receptor acts to scavenge and clear AGE and pro- 
teins modified by AGE from the body. ${ }^{3}$ Levels of RAGE are decreased in some people with type II diabetes, increasing the risk of peripheral neuropathy. ${ }^{3}$ RAGE also releases cytokines that remodel blood vessels, similar to the remodeling seen in atherosclerosis. ${ }^{3}$ These released cytokines may also increase ROS production, and this event combined with the tissue remodeling converts the short-term inflammatory signaling of AGE into long-term inflammation. ${ }^{3}$ The loss of insulin and $\mathrm{C}$ peptide in type I diabetes leads to a reduced ability to upregulate neurotrophic factors, which generally assist in nerve regeneration after a crush injury. ${ }^{3}$ Nerve growth factor (NGF) signaling plays a role in the development of neuropathic pain; the pattern of NGF's expression is dependent on the type of diabetes and can reduce regenerative ability if levels fall, which is seen later in the course of disease in some diabetic patients. ${ }^{3}$

Various chemotherapeutic agents, like paclitaxel and HIV infection and treatment with antiretrovirals, increase inflammation, which damages nerves, ganglia, and axons. ${ }^{3}$ The cryoglobulinemia seen in some cases of HCV precipitates a more generalized peripheral neuropathy rather than a localized disorder due to IgGs binding and initiating immune attack of myelin, and small and medium vascular occlusion leading to ischemic nerve damage. ${ }^{3}$ In HCV without cryoglobulinemia, interferon- $\alpha$ (IFN- $\alpha$ ) release can lead to peripheral neuropathy by damaging myelin and vasa vasorum, leading to ischemic nerve injury. ${ }^{3}$

The endoplasmic reticulum (ER) is susceptible to injury by several toxicities, and its dysfunction can lead to peripheral nerve damage by triggering cell death through different pathways. ${ }^{3}$ Dysfunction of mitochondria, especially overproduction of reactive oxygen species (ROS), can cause neuropathy through cell death and injury due to oxidative stress. ${ }^{3}$ This problem occurs with diabetes, HIV, treatment with chemotherapeutics like paclitaxel, bortezomib, and oxaliplatin, and with some antiretroviral medications. ${ }^{3}$

The nervous system is especially predisposed to free radical damage because of its high energy demands and increased lipid content. ${ }^{3,17}$ Natural antioxidants like uncoupling proteins (UCPs) protect cells from free radical damage, and depletion of these proteins due to decreased expression of UCP-3 in hyperglycemic states leads to nerve damage. $^{3}$

DNA damage from ROS like superoxide activates poly (ADP-ribose) polymerase (PARP) in several tissues, including Schwann cells and peripheral nerves. ${ }^{3}$ PARP depletes $\mathrm{NAD}^{+}$levels, resulting in neurotoxicity and necrosis. ${ }^{3}$ With an increase in ROS usually comes an increase in the production of reactive nitrogen species (RNS); PARP activation by ROS increases iNOS activity in the nervous system and decreases eNOS activity in endothelial cells. The combination of increased RNS in the nervous system and impairment of NO's vasodilatory effect on blood vessels causes a double insult to neurons through oxidant damage and hypoxia. ${ }^{3}$

Defects in axonal transport can lead to peripheral neuropathy. Slowed axonal transport of cytoskeletal proteins has been observed in diabetes, resulting in reduced levels of important proteins distally. ${ }^{3}$ Glycation of actin and neurofilaments also occurs with hyperglycemia, which is thought to disrupt axonal transport, making nerves less efficient in response to injury or environmental changes. ${ }^{3}$ Microtubule stabilization by taxanes like paclitaxel can also alter transport dynamics in nerves, which is another mechanism behind CIPN. ${ }^{14}$ Alterations in axonal transport can also be seen in CIPN caused by cisplatin and bortezomib, but the mechanism behind this remains unknown. ${ }^{14}$

When ion channel expression or dynamics in nerves are altered, this can cause peripheral neuropathy. Ion channel toxicity is a common cause of CIPN, especially with platinum chemotherapeutics and proteasome inhibitors, and in Guillain-Barré Syndrome (GBS). ${ }^{3,14}$ GBS is a syndrome of peripheral neuropathy caused by an autoimmune attack on gangliosides due to molecular mimicry of $C$. jejuni antigens, and this alters ion channel activity in the nodes of Ranvier. ${ }^{3}$

Diabetes, smoking, atherosclerosis, high blood pressure, and peripheral vascular disease can lead to inadequate oxygen supply to peripheral nerves and, in some cases, neuropathy. ${ }^{18}$ Burn injuries can also lead to peripheral neuropathy by direct injury or edema of soft tissues, inflammatory damage, or immobilization. ${ }^{19}$ Many of the mechanisms discussed here are inherently linked, with some pathologic processes enhancing others, creating a snowball effect of peripheral nerve damage. There are several other etiologies and pathophysiologic mechanisms that are still being discovered and explored further.

\section{CLINICAL PRESENTATION}

Peripheral neuropathy has a wide range of presentations depending on the underlying etiology. It can be asymptomatic or subclinical, where the patient has not noticed any symptoms, but this can predispose them to injuries or ulcer development. Symptoms will vary with the type of nerve fiber that is damaged. Damage to motor nerves may present with weakness, atrophy, fasciculations, or areflexia. In contrast, damage to large-fiber sensory nerves can cause loss of vibratory sensation or proprioception and can present with numbness, imbalance, falls, ataxia, paresthesia, or areflexia. ${ }^{6}$ Small-fiber sensory nerve damage can cause loss of pain/temperature sensation or can present with numbness or neuropathic pain described as burning, stinging, or aching. ${ }^{4}$ Autonomic nerve fiber damage can lead to postural dizziness due to orthostatic hypotension, dry mucous membranes, skin, coldness or flushing, bladder dysfunction, impotence, early satiety, skin changes, and hair loss. ${ }^{2}$

The most common presentation of peripheral neuropathy is a length-dependent, slowly progressing, distal symmetric polyneuropathy (DSP). ${ }^{6}$ Diabetes is the most common cause of DSP and commonly presents with numbness, paresthesia, loss of pain sensation, imbalance, or dysesthesia. ${ }^{2}$ These neurological deficits gradually spread, starting in the toes and moving proximally, eventually affecting the upper limbs in what is classically described as a 'glove-andstocking' pattern. ${ }^{8}$ Axons can be several feet long, and the most distal ends are more susceptible to damage, which explains the symmetric length dependency seen in DSP. ${ }^{17}$

Presentation with asymmetric or non-length-dependent neuropathies is rarer and will change the differential diagnosis; for example, a mononeuropathy could be due to direct trauma via laceration or compression of nerves. ${ }^{2}$ Presentation with an acute or subacute course may suggest an infectious process, toxic exposure, or an autoimmune eti- 
ology such as GBS or vasculitis. ${ }^{4,6}$ If motor symptoms prevail over sensory deficits, demyelinating disorders should be considered, including lead toxicity, porphyria, diphtheria, paraneoplastic neuropathy, multifocal motor neuropathy, chronic inflammatory demyelinating polyneuropathy, or a hereditary neuropathy such as Charcot-Marie-Tooth disease. $^{6}$

Later complications of long-standing peripheral neuropathy include ulcers, gangrene, distal calf atrophy, hammertoes, pes cavus, and lower extremity amputation. ${ }^{6}$

\section{CURRENT TREATMENT OF PERIPHERAL NEUROPATHY}

\section{ANTIDEPRESSANTS}

Serotonin and norepinephrine reuptake inhibitors (SNRIs) have been shown to improve peripheral neuropathy pain symptoms in diabetic peripheral neuropathy (DPN), chemotherapy-induced peripheral neuropathy (CIPN), and drug-induced peripheral neuropathy (DIPN). ${ }^{20-22}$ Tricyclic antidepressants (TCAs) have also been shown to treat DPN; however, there is less evidence than SNRIs. ${ }^{20,21}$ Of all antidepressants, duloxetine has the most data supporting its use in treating peripheral neuropathy. Multiple reviews show duloxetine is the most effective at treating symptoms of DPN and CIPN. ${ }^{20,21,23,24}$ The American Diabetes Association and American Society of Clinical Oncology recommend duloxetine as first-line treatment for DPN and CIPN. ${ }^{25,26}$ Venlafaxine has also been shown to help treat DPN, although less effective than duloxetine. ${ }^{20,21}$ A 2017 review by Waldfogel et al. demonstrated that 7 RCTs are testing the efficacy of duloxetine and 2 RCTs testing the efficacy of Venlafaxine. ${ }^{20}$ Due to the limited data of Venlafaxine's effectiveness, it is not recommended to treat peripheral neuropathies. ${ }^{26}$ These RCTs show that both drugs are effective treatments for DPN with a moderate level of evidence. ${ }^{20}$ Few RCTs are testing the efficacy of TCAs, but the data indicates that TCAs, specifically amitriptyline, nortriptyline, and imipramine are effective at treating DPN and DIPN. ${ }^{20,22}$

\section{ANTICONVULSANTS}

Pregabalin and gabapentin are shown to be effective for treating pain related to DPN, with pregabalin and duloxetine being the recommended first-line treatment by the American Diabetes Association. ${ }^{25,27}$ While both pregabalin and gabapentin are recommended for use to treat DPN. Pregabalin has been studied the most, with a recent review showing 16 RCTs investigating its efficacy versus placebo. ${ }^{20}$ The results from the RCTs show that pregabalin is effective in treating DPN but with a lower level of evidence than treatment with duloxetine. ${ }^{20}$ Gabapentin and Oxcarbazepine have also been studied in multiple RCTs but were less effective than treating DPN with pregabalin. ${ }^{20}$ Anticonvulsants are also used to treat CIPN and DIPN, but there is less evidence supporting their effectiveness. ${ }^{21,22}$

\section{OPIATES}

Typical opiates have not shown any statistically significant evidence of effectiveness at treating pain related to DPN, CIPN, and DIPN. However, atypical opiates, such as Tramadol, show limited efficacy. ${ }^{20,27}$ Sometimes, opiates are used in cases where peripheral neuropathy symptoms are refractory to antidepressants and anticonvulsants, but data does not show a decrease in peripheral neuropathy symptoms. ${ }^{28}$ Opiates are the gold standard for treating peripheral neuropathy and nerve impingement in burn patients. ${ }^{29}$ To treat peripheral neuropathy in burn patients, combining morphine and gabapentin show an increased reduction in symptoms than either alone. ${ }^{29}$ Other than this specific case, opiates are generally not recommended for treating peripheral neuropathies.

\section{OTHER/NON-PHARMACOLOGICAL TREATMENT}

Many non-pharmacological options are being explored as many cases remain refractory to pharmacological treatment, but few have been tested in large RCTs. When treating DPN, the most crucial step is maintaining low Hemoglobin A1C levels. In type I and people with type II diabetes, tight glucose control is effective at preventing DPN. ${ }^{25}$ Other effective non-pharmacological agents for treating DPN include alpha-lipoic acid (ALA), botulinum toxin A, and spinal cord stimulation. Oral $600 \mathrm{mg}$ ALA demonstrated the highest symptom relief compared to placebo, but some RCTs had an increased risk of bias. ${ }^{27,30}$ Multiple reviews show that intradermal injection into the dorsum of the foot with botulinum toxin $\mathrm{A}$ is more effective than placebo at relieving DPN. ${ }^{20,21,27,30}$ Spinal cord stimulation leads to reduced pain symptoms. Still, it is an invasive procedure with many harmful side effects. ${ }^{30}$ There are fewer recent investigations into non-pharmacological treatment for CIPN, but some RCTs have found that acupuncture improves symptoms when combined with other treatment methods. ${ }^{28}$ The studies regarding acupuncture have few participants and will require more extensive studies to prove its efficacy. Another recommended treatment by the American Society of Clinical Oncology is a topical compound gel consisting of baclofen, amitriptyline $\mathrm{HCl}$, and ketamine. ${ }^{26}$ Regarding DIPN, the most important treatment is to stop the offending agent. ${ }^{22}$ If the symptoms persist beyond that point, the next step would be to move on to duloxetine. ${ }^{22}$ A less common etiology of peripheral neuropathy is due to systemic and non-systemic vasculitis syndromes. Severe systemic vasculitis is treated with corticosteroids initially, and cyclophosphamide or rituximab can be added if symptoms persist, while non-systemic vasculitis is treated with corticosteroids only. ${ }^{31}$

\section{MECHANISM OF ACTION}

The pathophysiology of neuropathic pain is related to a change in the expression of sodium channels, which leads to aberrant pain responses. ${ }^{32}$ The main analgesic effect of lidocaine is mediated or modulated by desensitizing peripheral nociceptors through blockage of membrane sodium channels leading to adequate local anesthesia. ${ }^{32}$ This phys- 
iological effect is typically achieved through injections of higher doses of lidocaine. Lower dose intravenous (IV) infusion of lidocaine produces an analgesic effect by blocking voltage-gated sodium channels in the central nervous system. ${ }^{33-35}$ Binding of lidocaine to these ion channels causes reduced peak sodium current and speeds up the ion channel deactivation process. ${ }^{34}$ Lidocaine binds allosterically in the third or fourth domain of sodium channels, preferably in the open state, thus preventing ion flow. ${ }^{33}$ The lidocaine molecule also inserts into the cell membrane on the intracellular side. ${ }^{33}$ Inserting into the membrane brings lidocaine near sodium channels and also hyperpolarizes the resting cell membrane potential. ${ }^{33}$ IV lidocaine injection mainly exerts its effects in the spinal cord and dorsal root ganglia (DRG) ${ }^{34}$ Numerous other ion channels can have altered activity by lidocaine binding. The activity includes voltage-gated potassium channels in the DRG, hyperpolarization-activated cyclic nucleotide $(\mathrm{HCN})$ channels, and $\mathrm{N}$ methyl-D-aspartate (NMDA) receptors. ${ }^{34,35}$ Binding to potassium channels in the DRG and HCN channels decreases action potential firing and plays an important role in spinal anesthesia. ${ }^{34}$ Lidocaine binding to post-synaptic potassium channels also causes hyperpolarization. ${ }^{35}$ Lidocaine affects NMDA receptors through a cellular signaling pathway by inhibiting protein kinase $\mathrm{C}$ preventing postsynaptic depolarization. ${ }^{35}$ The experiments elucidating lidocaine's effects on ion channels have mostly been through animal models. In an effort to determine the mechanism of action of lidocaine in humans, experiments are limited to subjective pain scores and neurosensory testing. The experiments show that IV lidocaine reduced spontaneous pain and mechanical hyperalgesia in patients with spinal cord injuries. 36

Lidocaine infusion also has anti-inflammatory properties, which are stronger and have a smaller risk of adverse side effects compared to typical anti-inflammatories. ${ }^{37}$ This effect is due to a lower level of circulating inflammatory cytokines, leading to a decreased pain sensation. ${ }^{37}$ IV lidocaine also increases acetylcholine levels in cerebrospinal fluid, which has an inhibitory effect on descending pain pathways. ${ }^{33}$

\section{PHARMACOKINETICS/PHARMACODYNAMICS}

Following an IV infusion of lidocaine, plasma concentration rapidly falls and steadily declines at a slower pace with a half-life of roughly 100 minutes. ${ }^{38}$ Lidocaine reaches a wide distribution volume range of $0.6-4.5 \mathrm{~L} / \mathrm{kg} .{ }^{39}$ It is then metabolized to monoethylglycinexylidide (MEGX) and glycinexylidide (GX) by the hepatic enzyme CYP3A4. ${ }^{40,41}$ Less than $5 \%$ of lidocaine is renally excreted due to its lipophilicity. ${ }^{42}$ For renal excretion to occur, lidocaine must first be converted into its metabolites MEGX and 4-hydroxy-xylidine. ${ }^{41,42} \mathrm{GX}$ is further converted into xylidine and then finally to 4-hydroxy-xylidine, which is then excreted renally. ${ }^{41}$ MEGX is a pharmacologically active metabolite with a longer half-life but less potency than a sodium channel blocker. ${ }^{39}$ When patients are administered the CYP3A4 inhibitor erythromycin, clearance decreases by half, steady-state volume increases, and half-life doubles. ${ }^{41}$ Similar results are seen when patients are administered cimetidine before receiving IV lidocaine. Oral cimetidine causes lidocaine clearance to decrease by $34 \% .{ }^{43}$ Previous studies determined that infusion rate should not exceed $4 \mathrm{mg} / \mathrm{min} .{ }^{44}$ The ideal plasma concentration of lidocaine should not exceed $5.0 \mathrm{ug} / \mathrm{mL}$ as higher levels lead to a greater chance of toxicity. ${ }^{44}$ Dosages need to be decreased in patients with cardiac or liver failure, as these patients are more likely than healthy patients to reach toxic plasma concentrations. Heart failure patients will have a longer halflife and a smaller volume of distribution. ${ }^{38}$ Liver failure patients have an increased half-life, larger volume of distribution, and decreased plasma clearance. ${ }^{38}$ Lidocaine dosing in patients with renal failure can remain the same as dosing in healthy patients. In these patients, half-life, the volume of distribution, and plasma clearance remained similar to healthy patients. ${ }^{42}$ There is limited evidence regarding therapeutic index and other pharmacodynamics and kinetics specific to treating peripheral neuropathy, as treating cardiac arrhythmias is the purpose of most studies investigating IV lidocaine infusion. Overall, the pharmacokinetics and pharmacodynamics of IV lidocaine vary significantly from individual to individual.

\section{CLINICAL STUDIES: SAFETY AND EFFICACY}

The use of intravenous (IV) lidocaine infusions for treating peripheral neuropathy is a generally safe and effective treatment method for neuropathic pain. Potential adverse effects of or reactions to lidocaine infusion therapy (LIT) include but are not limited to dizziness, headaches, blurred vision, tinnitus, nausea, paresthesia, confusion, tremor, hypotension, bradycardia, arrhythmia, muscle twitching, seizures, cardiac arrest, and respiratory depression. ${ }^{45} \mathrm{Se}$ vere adverse effects were rare in the clinical trials reviewed below.

A randomized, double-blind, placebo-controlled, parallel study was conducted to evaluate the safety and efficacy of LIT in patients with postherpetic neuralgia or complex regional pain syndrome type II. Forty-two subjects were evenly and randomly split into two groups: the LIT group and the control group. The LIT group received lidocaine infusions dosed at $3 \mathrm{mg} / \mathrm{kg}$ over one hour; the control group received infusions of normal saline. Infusions were administered once a week for four weeks. The primary outcome measured was the percent change from baseline to after the final infusion on an 11-point numerical rating scale (NRS) pain score and NRS pain scores at the one-week and fourweek follow-ups. Following the final infusion, the NRS pain score percent decrease was significantly higher in the LIT group than in the control group $(\mathrm{P}=0.011)$. At the one-week and four-week follow-ups, no significant decrease in NRS pain scores were observed from baseline in both groups. Participants did not experience any severe complications from LIT and laboratory tests were normal. LIT was briefly stopped for one patient who in the past experienced chest discomfort; treatment was resumed after the discomfort resolved 15 minutes later. ${ }^{45}$

Another randomized, controlled, double-blind trial also evaluated lidocaine as a treatment for peripheral neuropathy. This single-site study investigated IV lidocaine infusion and utilized an active placebo infusion of diphenhy- 
Table 1. Clinical Efficacy and Safety

\begin{tabular}{|c|c|c|c|}
\hline $\begin{array}{l}\text { Author } \\
\text { (Year) }\end{array}$ & Groups Studied and Intervention & Results and Findings & Conclusions \\
\hline $\begin{array}{l}\text { Kim Y.C. et } \\
\text { al. }(2018)^{45}\end{array}$ & $\begin{array}{l}\text { A randomized, double-blind, placebo- } \\
\text { controlled, parallel study on LIT in } \\
\text { patients with postherpetic neuralgia or } \\
\text { complex regional pain syndrome type II. } \\
42 \text { participants evenly split into LIT and } \\
\text { control groups. LIT group received LIT } \\
\text { dosed at } 3 \mathrm{mg} / \mathrm{kg} \text { over one hour. The } \\
\text { Control group received normal saline over } \\
\text { one hour. }\end{array}$ & $\begin{array}{l}\text { Percent decrease in the NRS pain score } \\
\text { from baseline post-infusion was } \\
\text { significantly higher }(\mathrm{P}=0.011) \text { in the LIT } \\
\text { group compared to the control group. At } \\
\text { the } 1 \text { week and } 4 \text {-week follow-ups, there } \\
\text { was no significant decrease in NRS pain } \\
\text { scores from baseline in both groups. }\end{array}$ & $\begin{array}{l}\text { LIT is effective } \\
\text { after infusion and } \\
\text { in the short term, } \\
\text { but it is not } \\
\text { effective for long- } \\
\text { term pain relief. It } \\
\text { is safe and well- } \\
\text { tolerated, with } \\
\text { serious } \\
\text { complications } \\
\text { being rare. }\end{array}$ \\
\hline $\begin{array}{l}\text { Moulin D.E. } \\
\text { et al. } \\
(2019)^{46}\end{array}$ & $\begin{array}{l}\text { Randomized, controlled, double-blind trial } \\
\text { on LIT for peripheral neuropathy. } 34 \\
\text { participants were split into lidocaine and } \\
\text { placebo groups with } 16 \text { and } 18 \\
\text { participants, respectively. The lidocaine } \\
\text { group received a } 5 \mathrm{mg} / \mathrm{kg} \text { dosage and the } \\
\text { placebo group received } 50 \mathrm{mg} \text { IV } \\
\text { diphenhydramine. Infusions were given } \\
\text { over } 45 \text { minutes. Results evaluated } 4 \\
\text { weeks post-infusion, participants } \\
\text { switched into the opposite group, } \\
\text { experiment repeated. }\end{array}$ & $\begin{array}{l}\text { The API was obtained before infusions, } \\
6 \text { hours after, and daily for } 4 \text { weeks. No } \\
\text { significant differences were noted in API } \\
\text { from baseline compared to } 6 \text { hours after } \\
\text { infusions or any point thereafter. After } 4 \\
\text { weeks, the API difference between the } \\
\text { lidocaine group ( } 6.58 \text { mean, } 1.97 \text { SD) } \\
\text { and the control group }(6.78,1.56 \mathrm{SD}) \\
\text { was not significant }(P=0.61) \text {. }\end{array}$ & $\begin{array}{l}\text { LIT is not } \\
\text { effective in the } \\
\text { short or long } \\
\text { term. It is safe and } \\
\text { well-tolerated, } \\
\text { with serious } \\
\text { complications } \\
\text { being rare. }\end{array}$ \\
\hline $\begin{array}{l}\text { Van Den } \\
\text { Heuvel } \\
\text { S.A.S. et. al. } \\
(2017)^{47}\end{array}$ & $\begin{array}{l}\text { Cohort study with } 9 \text { patients to determine } \\
\text { effects of IV lidocaine for treating CIPN. } \\
\text { The infusion dose was } 1.5 \mathrm{mg} / \mathrm{kg} \text { over } 10 \\
\text { minutes, followed by } 1.5 \mathrm{mg} / \mathrm{kg} / \text { hour over } \\
5 \text { hours. }\end{array}$ & $\begin{array}{l}\text { Pre-infusion NRS scores ranged from } \\
5-9 \text { ( } 7.7 \text { average). Post-infusion NRS } \\
\text { scores ranged from 0-7 (average } 3.1 \text { ). } \\
\text { LIT resulted in a clinically significant } \\
\text { decrease in NRS scores ( } P=0.01 \text { ). } 3 \\
\text { patients reported cessation of the } \\
\text { effects immediately after completion of } \\
\text { the infusion. } 5 \text { patients experienced } \\
\text { analgesic effects ranging from } 3-56 \text { days } \\
\text { (average } 23 \text { days) after completion of } \\
\text { the infusion. }\end{array}$ & $\begin{array}{l}\text { LIT is significantly } \\
\text { effective at } \\
\text { reducing pain } \\
\text { during infusions. } \\
\text { Results are mixed } \\
\text { regarding the } \\
\text { continuation of } \\
\text { effects after } \\
\text { treatment with } \\
\text { some people. It is } \\
\text { safe and well- } \\
\text { tolerated, with } \\
\text { serious } \\
\text { complications } \\
\text { being rare. }\end{array}$ \\
\hline $\begin{array}{l}\text { Liu H. et al. } \\
(2018)^{48}\end{array}$ & $\begin{array}{l}\text { Randomized, double-blind, placebo- } \\
\text { controlled study regarding the LIT } \\
\text { treatment of PHN. } 197 \text { patients were split } \\
\text { into a lidocaine group ( } 96 \text { patients) and a } \\
\text { placebo group ( } 101 \text { patients). The } \\
\text { lidocaine group received an infusion dose } \\
\text { of } 5 \mathrm{mg} / \mathrm{kg} \text { and the placebo group received } \\
\text { normal saline over } 1.5 \text { hours. }\end{array}$ & $\begin{array}{l}14 \text { patients withdrew, leaving } 183 \\
\text { patients. The average baseline VAS of } \\
\text { the lidocaine and placebo groups were } \\
5.18 \text { and } 4.99 \text {, respectively. Post- } \\
\text { infusion VAS scores reached their } \\
\text { minimum in both groups after } 2 \text { weeks. } \\
\text { Lidocaine group VAS: } 2.74 \text {. Placebo } \\
\text { group VAS: } 2.99 \text {. VAS scores slightly } \\
\text { increased at the 4-week mark. }\end{array}$ & $\begin{array}{l}\text { The difference in } \\
\text { VAS scores is not } \\
\text { clinically } \\
\text { significant and } \\
\text { reduction of pain } \\
\text { with LIT is } \\
\text { comparable to the } \\
\text { placebo. It is safe } \\
\text { and well- } \\
\text { tolerated, with } \\
\text { serious } \\
\text { complications } \\
\text { being rare. }\end{array}$ \\
\hline $\begin{array}{l}\text { Przeklasa- } \\
\text { Muszyńska } \\
\text { A. et. al. } \\
(2016)^{49}\end{array}$ & $\begin{array}{l}85 \text { patients with various neuropathic pain } \\
\text { syndromes received LIT. } 81 \text { patients } \\
\text { received } 3-25 \text { infusions and } 4 \text { patients } \\
\text { withdrew after the first infusion. The } \\
\text { average age of patients was } 62.6 \text { years, } \\
\text { with } 43 \% \text { male patients and } 57 \% \text { female } \\
\text { patients. }\end{array}$ & $\begin{array}{l}\text { No significant difference between the } \\
\text { sexes regarding pain/symptom } \\
\text { reduction was found. The pre-infusion } \\
\text { average NRS score was 7.01; the post- } \\
\text { infusion score was } 2.8 \text {. There was a } 40 \% \\
\text { average reduction in pain. The older the } \\
\text { patient, the more effective LIT is. } \\
\text { Patients with higher NRS pain scores } \\
\text { pre-infusion reported the most relief. } \\
\text { These differences were statistically } \\
\text { significant. }\end{array}$ & $\begin{array}{l}\text { LIT is effective at } \\
\text { reducing pain and } \\
\text { symptoms of } \\
\text { neuropathic pain. } \\
\text { It is safe and well- } \\
\text { tolerated, with } \\
\text { serious } \\
\text { complications } \\
\text { being rare. }\end{array}$ \\
\hline $\begin{array}{l}\text { Hutson P. } \\
\text { et al. } \\
(2015)^{50}\end{array}$ & $\begin{array}{l}69 \text { patients received a total of } 1650 \\
\text { infusions dosed at } 500 \mathrm{mg} \text { lidocaine in } 100 \\
\mathrm{~mL} \text { saline over } 30 \text { minutes ( } 16.7 \mathrm{mg} / \mathrm{min}) \text {. }\end{array}$ & $\begin{array}{l}\text { The average pain decrease was } 3.6 \\
\text { points (SD 1.7). Most patients needed a } \\
\text { dose reduction or rate adjustment. } 89 \%\end{array}$ & $\begin{array}{l}\text { The study bases } \\
\text { efficacy on the } \\
\text { fact that } 1579 /\end{array}$ \\
\hline
\end{tabular}




\begin{tabular}{|c|c|c|c|}
\hline & $\begin{array}{l}\text { The initial high dosage is given to } \\
\text { determine patient response and tolerance. }\end{array}$ & $\begin{array}{l}\text { of infusion rates ranged from } 4-14 \mathrm{mg} / \\
\text { min, an average of } 9.1 \mathrm{mg} / \mathrm{min} \text {. A } \\
\text { significant number of patients } \\
\text { experienced the greatest pain relief } 24 \\
\text { hours post-infusion. A dose between } \\
4-12 \mathrm{mg} / \mathrm{min} \text { was the most tolerable } \\
\text { effective dose. Patients experienced } \\
\text { adverse side effects at an average of } \\
13.1 \mathrm{mg} / \mathrm{min} \text {. }\end{array}$ & $\begin{array}{l}1650 \text { infusions } \\
(95.7 \%) \text { were } \\
\text { done on repeat } \\
\text { patients as they } \\
\text { continued } \\
\text { treatment. LIT is } \\
\text { safe and well- } \\
\text { tolerated, with } \\
\text { serious } \\
\text { complications } \\
\text { being rare. }\end{array}$ \\
\hline $\begin{array}{l}\text { Papapetrou } \\
\text { P. et al. } \\
(2015)^{51}\end{array}$ & $\begin{array}{l}\text { Case report of LIT to treat CIPN in a } \\
61 \text {-year-old female. } 5 \mathrm{mg} / \mathrm{kg} \text { IV lidocaine } \\
\text { was administered over } 1 \text { hour. }\end{array}$ & $\begin{array}{l}\text { Symptoms were immediately alleviated } \\
\text { following the infusion and the results } \\
\text { lasted } 2 \text { weeks. The treatment was } \\
\text { repeated and yielded similar results. } 3 \\
\text { more infusions were given over the next } \\
9 \text { weeks, and each infusion lasted } 2-3 \\
\text { weeks }\end{array}$ & $\begin{array}{l}\text { LIT is effective at } \\
\text { reducing pain for } \\
\text { up to } 3 \text { weeks } \\
\text { post-infusion. LIT } \\
\text { is safe and well- } \\
\text { tolerated, with } \\
\text { serious } \\
\text { complications } \\
\text { being rare. }\end{array}$ \\
\hline $\begin{array}{l}\text { Kajiume T. } \\
\text { et al. } \\
(2012)^{52}\end{array}$ & $\begin{array}{l}\text { Case report of a } 5 \text {-year-old girl with } \\
\text { severe neuropathic cancer pain due to } \\
\text { meningitis caused by malignant T-cell } \\
\text { lymphoma. The patient was co- } \\
\text { administered IV infusions of ketamine } \\
(0.12 \mathrm{mg} / \mathrm{kg} / \text { hour), fentanyl }(0.83 \mu \mathrm{g} / \mathrm{kg} / \\
\text { hour), and lidocaine }(9.3-14 \mu \mathrm{g} / \mathrm{kg} / \mathrm{min}) \text {. }\end{array}$ & $\begin{array}{l}\text { This combination proved very effective } \\
\text { as it significantly reduced her pain for } \\
\text { two weeks. }\end{array}$ & $\begin{array}{l}\text { The combination } \\
\text { administered was } \\
\text { safe and very } \\
\text { effective in this } \\
\text { patient. }\end{array}$ \\
\hline $\begin{array}{l}\text { Park C.H. } \\
\text { et al. } \\
(2012)^{53}\end{array}$ & $\begin{array}{l}\text { A randomized, double-blind, prospective, } \\
\text { crossover study with } 18 \text { patients was } \\
\text { conducted to evaluate the efficacy of LIT } \\
\text { on FBSS. Each patient received } 3 \text { different } \\
\text { IV infusions on } 3 \text { different days, } 2 \text { weeks } \\
\text { apart. Infusions were given over the } \\
\text { course of } 1 \text { hour. Patients randomly } \\
\text { received either a } 0.9 \% \text { normal saline } \\
\text { placebo, } 1 \mathrm{mg} / \mathrm{kg} \text { of lidocaine, or } 5 \mathrm{mg} / \mathrm{kg} \\
\text { of lidocaine IV infusion per infusion day. }\end{array}$ & $\begin{array}{l}\text { VAS scores at baseline compared to } \\
\text { post-infusion showed all } 3 \text { treatments } \\
\text { demonstrated a significant decrease in } \\
\text { pain ( } P=0.006) \text {. The NPS scale showed } \\
\text { there was not a statistically significant } \\
\text { difference in pain between the } 3 \\
\text { treatments except for sharp, cold, dull, } \\
\text { and deep pain. }\end{array}$ & $\begin{array}{l}\text { All } 3 \text { treatments } \\
\text { were effective in } \\
\text { reducing } \\
\text { neuropathic pain } \\
\text { due to FBSS, } \\
\text { including the } \\
\text { placebo. LIT was } \\
\text { as effective as the } \\
\text { placebo. Patients } \\
\text { did not } \\
\text { experience any } \\
\text { serious } \\
\text { complications } \\
\text { during or after } \\
\text { treatment. }\end{array}$ \\
\hline
\end{tabular}

dramine. Thirty-four eligible participants were enrolled and randomly split into a lidocaine group with 16 participants and a placebo group with 18 participants. In the first phase, the lidocaine group received an infusion dose of $5 \mathrm{mg} / \mathrm{kg}$ and the placebo group received a dose of $50 \mathrm{mg}$, infusions were given over 45 minutes. Results were evaluated four weeks post-infusion, after which participants were switched into the opposite group, and the experiment was repeated for phase two. The average pain intensity (on a scale of 0 -10) difference between lidocaine infusion and placebo infusion four weeks post-infusion was the primary outcome measure. The average pain intensity (API) was obtained before infusions, 6 hours after infusions, and daily for four weeks. No significant differences were noted in API from baseline compared to 6 hours after infusions or any point after that. At the end of the four weeks, the API difference between the lidocaine group (6.58 mean, 1.97 SD) and the control group (6.78, $1.56 \mathrm{SD})$ was not significant $(\mathrm{P}=0.61)$. Participants did not experience any serious complications during or after treatment. ${ }^{46}$

Nine patients were enrolled in a cohort observational study to determine the effects of IV lidocaine on treating chemotherapy-induced peripheral neuropathy (CIPN). The lidocaine infusion dose was $1.5 \mathrm{mg} / \mathrm{kg}$ over 10 minutes, followed by $1.5 \mathrm{mg} / \mathrm{kg} /$ hour over 5 hours. Pain intensity was determined using the 11-point NRS scale before, during, and after treatment. Pre-infusion NRS scores ranged from 5 to 9 , with an average of 7.7. Post-infusion NRS scores ranged from 0 to 7 , with an average of 3.1. IV lidocaine treatment resulted in a clinically significant decrease in NRS scores at the group level $(\mathrm{P}=0.01)$. Three patients reported cessation of the analgesic effects almost immediately after completion of the infusion. Five patients continued to experience analgesic effects ranging from 3 to 56 days after completion of the infusion, with an average of 23 days. ${ }^{47}$

A randomized, double-blind, placebo-controlled study evaluated the analgesic effects of IV lidocaine infusion to treat postherpetic neuralgia (PHN). A total of 197 eligible patients were enrolled in the study, and they were randomized and split into a lidocaine group with 96 patients and a placebo group with 101 patients. The lidocaine group received an IV infusion dosed at $5 \mathrm{mg} / \mathrm{kg}$, and the placebo group received normal saline over 1.5 hours. The visual analog scale (VAS) was used to assess pain at baseline and after the infusion. Post-infusion, eight patients received a paravertebral block due to no improvement in pain from the IV 
lidocaine; they withdrew from the study. Six patients were lost to follow-up for other reasons, resulting in 183 patients with eligible data. The average baseline VAS score of the lidocaine group was 5.18 and the placebo group's average was 4.99. Post-infusion, the VAS scores decreased daily in both groups and reached their minimum scores after two weeks, with the lidocaine group have a score of 2.74 and the placebo group having a score of 2.99. This difference was determined not to be clinically significant; scores slightly increased at the 4-week mark. The reduction of pain using IV lidocaine was determined to be comparable to the placebo. Patients did not experience any serious complications during or after treatment. ${ }^{48}$

A total of 85 patients with various neuropathic pain syndromes were enrolled in a study that evaluated the efficacy of IV lidocaine. Eighty-one patients received 3 to 25 IV lidocaine infusions from this group, and four patients withdrew from the study after the first infusion due to inefficacy. Before each infusion, the patient rated their pain on the NRS scale. Each patient received an IV lidocaine infusion dosed at $5 \mathrm{mg} / \mathrm{kg}$ over 30 minutes once a week for 25 weeks. The average age of patients was 62.6 years, with $43 \%$ male patients and $57 \%$ female patients. There was no statistically significant difference between the sexes in terms of pain and symptom reduction. The pre-infusion average NRS pain value of all patients was 7.01 ; the post-infusion value was 2.8 . The average percentage of relief in pain symptoms was over 40\%. Przeklasa-Muszyńska et al., 2016 determined that LIT is more effective in older patients. The least efficacy was seen in the 20-to-30-year age group, effectiveness increased significantly in the 31 to 70 age group, and it was the most effective in the 71-90-year age group. It was also determined that the more infusions a patient received, the more effective the IV lidocaine therapy was. They also observed that the more intense the initial pain was reported to be, the more effective the treatment was to alleviate pain on the subjective NRS scale. These differences were found to be statistically significant. The length of time a patient had been experiencing pain did not affect the efficacy of the treatment as the difference in pain intensity on the NRS pre-infusion and post-infusion was significant irrespective of pain duration. Patients did not experience any serious complications during or after treatment. ${ }^{49}$

A study was conducted to determine the efficacy, safety, and toxicity of IV lidocaine infusions in treating neuropathic pain. The University of Wisconsin (UW) health infusions centers protocol is to administer $500 \mathrm{mg}$ of lidocaine in $100 \mathrm{~mL}$ of saline over 30 minutes, which comes to $16.7 \mathrm{mg} / \mathrm{min}$. This is done in the initial infusion to determine how and if the patient responds to and tolerates the therapy. A total of 69 patients received 1650 infusions. Only 262 of these infusions had comprehensive documentation, which included both pre-infusion and post-infusion NRS scores. The average decrease in pain was found to be 3.6 points (SD 1.7). Of the 69 patients, 58 were started on the institutional dose of $500 \mathrm{mg}$ lidocaine over $30 \mathrm{~min}$ utes. Fifteen of the 58 patients developed adverse effects and could not tolerate the dosage or required a reduction. The actual administered dose average was $364 \mathrm{mg}$ (SD 78 $\mathrm{mg}$ ) with an average rate of $9.1 \mathrm{mg} / \mathrm{min}$ (SD $3.31 \mathrm{mg} / \mathrm{min}$ ). A total of 45 patients continued with subsequent infusions.
Of the 45 patients, 23 tolerated the initial rate of $16.7 \mathrm{mg} /$ min. As well, 8 of these 23 patients received this rate on all future infusions. $89 \%$ of the IV lidocaine infusion rates ranged from $4-14 \mathrm{mg} / \mathrm{min}$ with an average of $9.1 \mathrm{mg} / \mathrm{min}$ when excluding the initial infusion of all patients. Of the 45 patients, 38 needed rate reductions and 26 of the 45 patients required a reduced dose. On average, patients received infusions every 19.4 days. Of the 1650 infusions, 38 were prematurely discontinued related to the development of adverse effects at a rate of $13.4 \mathrm{mg} / \mathrm{min}$. The data revealed that 55 (79.9\%) of the 69 patients developed adverse effects with an average rate of $13.2 \mathrm{mg} / \mathrm{min}$. The most common adverse effect was light-headedness, and any harmful effects were reversed. A significant number of patients reported that they experienced the greatest amount of pain relief 24 hours after the infusion. A total of 1579 of the 1650 infusions (95.7\%) were done on repeat patients; this can be used to measure the efficacy of the treatment as they chose to continue. A dose between 4 and $12 \mathrm{mg} / \mathrm{min}$ was found to be the most tolerable effective dose. The average dose at which patients experienced adverse side effects was 13.1 $\mathrm{mg} / \mathrm{min}$. Patients did not experience any serious complications during or after treatment except for one patient that developed hypoglycemia. However, as hypoglycemia is not associated with IV lidocaine, this was deemed circumstantial. ${ }^{50}$

A case report documented the efficacy of IV lidocaine infusions to treat chemotherapy-induced peripheral neuropathy. Many chemotherapy drugs can cause peripheral neuropathy. The incidence rate is approximately $30-40 \%$. A 61-year-old female presented to a pain clinic with hand and foot pain after receiving chemotherapy for breast cancer. After four months of treatment, she started to experience pain, tingling, and bilateral numbness, which were not alleviated with amitriptyline and gabapentin. $5 \mathrm{mg} / \mathrm{kg}$ IV lidocaine was administered over 1 hour in the clinic. The patient's symptoms were immediately alleviated following the infusion. The treatment lasted two weeks and was repeated once symptoms returned and yielded similar results. The patient has three more lidocaine infusions over the next nine weeks, and each infusion lasted 2-3 weeks. Treatment is safe and well-tolerated; the patient did not experience any severe complications. ${ }^{51}$

A 5-year-old girl was diagnosed with severe neuropathic cancer pain due to meningitis caused by malignant T-cell lymphoma. In children with terminal cancer, opioids are the go-to therapy selection. However, patients with tumors that have metastasized to the spine and have invaded nerves may need higher doses of opioids. This patient was administered IV infusions of ketamine, fentanyl, and lidocaine. The patient underwent chemotherapy and achieved remission. However, after one year after the onset of symptoms, she was diagnosed with a lymphoma recurrence. She was treated with chemotherapy, but complete remission wasn't achieved. An umbilical cord blood stem cell transplantation was performed. She developed oral ulcers, fatigue, headache, neck pain, vertigo, vomiting, right oculomotor paralysis, pressure in her head, and sharp pain secondary to trigeminal nerve involvement over 59 days after transplantation. Her symptoms were not controlled with fentanyl $(0.83 \mu \mathrm{g} / \mathrm{kg} /$ hour) alone and IV lidocaine (9.3-14 $\mu \mathrm{g} /$ 
Table 2. Comparative Studies

\begin{tabular}{|c|c|c|c|}
\hline $\begin{array}{l}\text { Author } \\
\text { (Year) }\end{array}$ & Groups Studied and Intervention & Results and Findings & Conclusions \\
\hline $\begin{array}{l}\text { Cousins } \\
\text { M.J. et al. } \\
(2013)^{54}\end{array}$ & $\begin{array}{l}\text { A double-blind, randomized, crossover trial } \\
\text { was conducted to compare the efficacy of } \\
\text { subcutaneous infusions of lidocaine ( } 700 \\
\text { mg), KAl-1678 ( } 25 \mathrm{mg} \text { ), and a placebo in } \\
\text { treating neuropathic pain in PHN patients. } \\
\text { KAI-1678 is an inhibitor of epsilon protein } \\
\text { kinase C. }\end{array}$ & $\begin{array}{l}\text { KAI-1678 did not reduce NRS pain scores. } \\
\text { Subcutaneous lidocaine infusions } \\
\text { significantly reduced pain intensity on the } \\
\text { NRS pain scale. }\end{array}$ & $\begin{array}{l}\mathrm{KAl}-1678 \text { is safe } \\
\text { and well- } \\
\text { tolerated. }\end{array}$ \\
\hline $\begin{array}{l}\text { Tremont- } \\
\text { Lukats I. } \\
\text { et. al. } \\
(2006)^{55}\end{array}$ & $\begin{array}{l}\text { A double-blind, parallel study was } \\
\text { conducted to evaluate the dose-response } \\
\text { effect and safety of LIT at various dosages } \\
\text { in patients with peripheral neuropathy. } \\
\text { Patients received an infusion over the } \\
\text { course of } 6 \text { hours. The infusions were dosed } \\
\text { at } 1 \mathrm{mg} / \mathrm{kg} / \mathrm{hour}, 3 \mathrm{mg} / \mathrm{kg} / \mathrm{hour}, 5 \mathrm{mg} / \mathrm{kg} / \\
\text { hour, or the infusion was a saline placebo }\end{array}$ & $\begin{array}{l}\text { A significant difference in the PID\% was } \\
\text { found between the placebo group and the } \\
\text { group that received } 5 \mathrm{mg} / \mathrm{kg} / \text { hour } \\
(\mathrm{P}=0.012) \text {. Pain reduction in this group } \\
\text { continued even after completion of the } \\
\text { infusion up to } 4 \text { hours post-infusion. The } \\
\text { results of the lower dosage lidocaine } \\
\text { groups were comparable to the placebo. }\end{array}$ & $\begin{array}{l}\text { LIT is effective } \\
\text { for short term } \\
\text { pain relief and it } \\
\text { is safe and well- } \\
\text { tolerated. } \\
\text { Patients did not } \\
\text { experience any } \\
\text { serious } \\
\text { complications } \\
\text { during or after } \\
\text { treatment. }\end{array}$ \\
\hline
\end{tabular}

$\mathrm{kg} / \mathrm{min}$ ) was co-administered on day 62 . She developed new neck and shoulder pain and on day 89 ketamine $(0.12 \mathrm{mg} /$ $\mathrm{kg}$ /hour) was co-administered with fentanyl and lidocaine to improve the analgesia. This combination of medication proved to be very effective as it significantly reduced her pain for two weeks, after which she died. The combination administered was safe and very effective in this patient. ${ }^{52}$

A randomized, double-blind, prospective, crossover study was conducted to evaluate the effects of IV lidocaine therapy on cases of failed back surgery syndrome (FBSS). Eighteen patients with FBSS were enrolled. Each patient received three different IV infusions on three different days, which were two weeks apart. Infusions were given over the course of 1 hour. The patient randomly received either a $0.9 \%$ normal saline placebo, $1 \mathrm{mg} / \mathrm{kg}$ of lidocaine, or $5 \mathrm{mg} /$ $\mathrm{kg}$ of lidocaine IV infusion per infusion day. The pain was assessed using the visual analog scale (VAS) and neuropathic pain scale (NPS). VAS scores were measured preinfusion, every 10 minutes during infusion, and 8, 16, 24 hours post-infusion. VAS scores at baseline were compared to scores post-infusion. All three treatments demonstrated a significant decrease in pain $(\mathrm{P}=0.006)$. According to the NPS scale, there was no statistically significant difference in pain between lidocaine dosages or between lidocaine and the placebo except for sharp, cold, dull, and deep pain. The three treatments were all effective in reducing neuropathic pain due to FBSS. However, the effects of the placebo did not differ from either lidocaine dosage. Patients did not experience any serious complications during or after treatment. 53

\section{CONCLUSION}

Peripheral neuropathy is a common complication of several systemic illnesses, drug therapies, and toxic exposures. Standard treatment either focuses on the underlying mechanisms of peripheral neuropathy, such as better glycemic control in diabetic patients, or symptomatic treatment. Es- pecially when the symptoms of peripheral neuropathy include neuropathic pain, pain management is the primary aspect of the treatment regimen. Antidepressants including duloxetine, epilepsy drugs such as pregabalin, local anesthetics/topical medications, and opioids have long been hallmarks of neuropathic pain treatment. ${ }^{8}$

Recently, several studies have examined the safety and efficacy of intravenous lidocaine infusion therapy in treating peripheral neuropathy. Lidocaine, a local amide anesthetic, has analgesic properties by blocking sodium channels and decreasing nociceptor sensitization. It also has strong anti-inflammatory properties with fewer side effects than other anti-inflammatory medications. ${ }^{37}$

Lidocaine infusion is not without its side effects, with the most common being light-headedness, dizziness, headache, tinnitus, lethargy, and paresthesia. These side effects were usually self-limiting and subsided shortly after the treatment ended; severe side effects were rare in the studies reviewed here. Lidocaine infusion therapy is especially promising due to its ability to provide pain relief for up to weeks after the drug is infused. ${ }^{37}$

Several studies have shown that intravenous lidocaine infusion is a safe and effective treatment for peripheral neuropathy. Even though some studies concluded that lowdose lidocaine infusions did not significantly affect placebo, higher doses showed significant pain improvement. The studies reviewed here showed a wide variation in administration, treatment timeline, and pain assessment, which may explain the variable results. More research with standardized measures on intravenous lidocaine infusion treatment for peripheral neuropathy is needed to fully understand the efficacy of this treatment. If studies continue to show encouraging results, lidocaine infusion can be a viable option for patients who have long struggled to find relief from their peripheral neuropathy symptoms. 


\section{DISCLOSURES}

The authors have nothing to disclose.
FUNDING

No external funding source was used for the generation of this publication.

Submitted: June 25, 2021 EST, Accepted: July 02, 2021 EST 


\section{REFERENCES}

1. Hanewinckel R, Drenthen J, van Oijen M, Hofman A, van Doorn PA, Ikram MA. Prevalence of polyneuropathy in the general middle-aged and elderly population. Neurology.

2016;87(18):1892-1898. doi:10.1212/WNL.000000000 $\underline{0003293}$

2. Pytel P, Anthony DC. Peripheral Nerves and Skeletal Muscles. In: Robbins \& Cotran Pathologic Basis of Disease. 10th ed. ; :1217-1240.

3. Cashman CR, Höke A. Mechanisms of distal axonal degeneration in peripheral neuropathies. Neurosci Lett. 2015;596:33-50. doi:10.1016/j.neulet.2015.01.04 $\underline{8}$

4. Barrell K, Smith AG. Peripheral Neuropathy. Med Clin North Am. 2019;103(2):383-397. doi:10.1016/i.mc na.2018.10.006

5. Stino AM, Smith AG. Peripheral neuropathy in prediabetes and the metabolic syndrome. J Diabetes Investig. 2017;8(5):646-655. doi:10.1111/jdi.12650

6. Doughty CT, Seyedsadjadi R. Approach to Peripheral Neuropathy for the Primary Care Clinician. Am J Med. 2018;131(9):1010-1016. doi:10.1016/j.amj med.2017.12.042

7. Girach A, Julian TH, Varrassi G, Paladini A, Vadalouka A, Zis P. Quality of Life in Painful Peripheral Neuropathies: A Systematic Review. Pain Res Manag. 2019;2019:1-9. doi:10.1155/2019/2091960

8. Iqbal Z, Azmi S, Yadav R, et al. Diabetic Peripheral Neuropathy: Epidemiology, Diagnosis, and Pharmacotherapy. Clin Ther. 2018;40(6):828-849. do i:10.1016/j.clinthera.2018.04.001

9. Watson JC, Dyck PJB. Peripheral Neuropathy: A Practical Approach to Diagnosis and Symptom Management. Mayo Clin Proc. 2015;90(7):940-951. do i:10.1016/i.mayocp.2015.05.004

10. Gregg EW, Sorlie P, Paulose-Ram R, et al. Prevalence of lower-extremity disease in the U.S. adult population $\geqslant 40$ years of age with and without diabetes: 1999-2000 National Health and Nutrition Examination Survey. Diabetes Care. 2004;27(7):1591-1597. doi:10.2337/diacare.27.7.1591

11. Hicks CW, Selvin E. Epidemiology of Peripheral Neuropathy and Lower Extremity Disease in Diabetes. Curr Diab Rep. 2019;19(10):86. doi:10.1007/s11892-01 9-1212-8
13. Abbott CA, Malik RA, Van Ross ERE, Kulkarni J, Boulton AJM. Prevalence and characteristics of painful diabetic neuropathy in a large communitybased diabetic population in the U.K. Diabetes Care. 2011;34(10):2220-2224. doi:10.2337/dc11-1108

14. Staff NP, Grisold A, Grisold W, Windebank AJ. Chemotherapy-induced peripheral neuropathy: A current review. Ann Neurol. 2017;81(6):772-781. doi:1 0.1002/ana.24951

15. Beran R. Paraesthesia and peripheral neuropathy. Aust Fam Physician. 2015;44(3):92-95.

16. Singh R, Kishore L, Kaur N. Diabetic peripheral neuropathy: Current perspective and future directions. Pharmacol Res. 2014;80:21-35. doi:10.101 6/j.phrs.2013.12.005

17. Staff NP, Windebank AJ. Peripheral Neuropathy Due to Vitamin Deficiency, Toxins, and Medications. Contin Lifelong Learn Neurol. 2014;20(5):1293-1306. $\underline{\mathrm{d}}$ oi:10.1212/01.CON.0000455880.06675.5a

18. Teunissen LL, Notermans NC, Wokke JHJ. Relationship between Ischemia and Neuropathy. Eur Neurol. 2000;44(1):1-7. doi:10.1159/000008185

19. Tu Y, Lineaweaver WC, Zheng X, Chen Z, Mullins F, Zhang F. Burn-related peripheral neuropathy: A systematic review. Burns. 2017;43(4):693-699. doi:1 $\underline{0.1016 / \text { i.burns.2016.08.003 }}$

20. Waldfogel JM, Wilson LM, Robinson KA. Author response: Pharmacotherapy for diabetic peripheral neuropathy pain and quality of life: A systematic review. Neurology. 2018;90(24):1123-1125. doi:10.121 2/WNL.0000000000005676

21. Dy SM, Bennett WL, Sharma R, et al. Preventing Complications and Treating Symptoms of Diabetic Peripheral Neuropathy. Comp Eff Rev. Published online 2017.

22. Jones MR, Urits I, Wolf J, et al. Drug-Induced Peripheral Neuropathy: A Narrative Review. Curr Clin Pharmacol. Published online 2019. doi:10.2174/15748 $\underline{84714666190121154813}$

23. Hou S, Huh B, Kim HK, Kim KH, Abdi S. Treatment of chemotherapy-induced peripheral neuropathy: Systematic review and recommendations. Pain Physician. Published online 2018. doi:10.36076/ppj.20 18.6.571 
24. Bakogeorgos M, Georgoulias V. Risk-reduction and treatment of chemotherapy-induced peripheral neuropathy. Expert Rev Anticancer Ther. Published online 2017. doi:10.1080/14737140.2017.1374856

25. Pop-Busui R, Boulton AJM, Feldman EL, et al. Diabetic neuropathy: A position statement by the American diabetes association. Diabetes Care. Published online 2017.

26. Hershman DL, Lacchetti C, Dworkin RH, et al. Prevention and management of chemotherapyinduced peripheral neuropathy in survivors of adult cancers: American society of clinical oncology clinical practice guideline. J Clin Oncol. Published online 2014. doi:10.1200/JCO.2013.54.0914

27. Çakici N, Fakkel TM, van Neck JW, Verhagen AP, Coert JH. Systematic review of treatments for diabetic peripheral neuropathy. Diabet Med. 2016;33(11):1466-1476. doi:10.1111/dme.13083

28. Kim PY, Johnson CE. Chemotherapy-induced peripheral neuropathy: A review of recent findings. Curr Opin Anaesthesiol. 2017;30(5):570-576. doi:10.10 97/ACO.0000000000000500

29. Strong AL, Agarwal S, Cederna PS, Levi B. Peripheral Neuropathy and Nerve Compression Syndromes in Burns. Clin Plast Surg. Published online 2017. doi:10.1016/i.cps.2017.05.010

30. Amato Nesbit S, Sharma R, Waldfogel JM, et al. Non-pharmacologic treatments for symptoms of diabetic peripheral neuropathy: a systematic review. Curr Med Res Opin. Published online 2019. doi:10.108 0/03007995.2018.1497958

31. Beachy N, Satkowiak K, Gwathmey KG. Vasculitic Neuropathies. Semin Neurol. Published online 2019. $\underline{\mathrm{d}}$ oi:10.1055/s-0039-1688990

32. Rogers M, Tang L, Madge DJ, Stevens EB. The role of sodium channels in neuropathic pain. Semin Cell Dev Biol. Published online 2006. doi:10.1016/i.semcd b.2006.10.009

33. Lauretti GR. Mechanisms of analgesia of intravenous lidocaine. Rev Bras Anestesiol. 2008;58(3):280-286. doi:10.1590/S0034-70942008000 $\underline{300011}$

34. Yang X, Wei X, Mu Y, Li Q, Liu J. A review of the mechanism of the central analgesic effect of lidocaine. Medicine. Published online 2020. doi:10.10 97/MD.0000000000019898

35. Estebe JP. Intravenous lidocaine. Best Pract Res Clin Anaesthesiol. Published online 2017. doi:10.1016/ j.bpa.2017.05.005
36. Attal N, Gaudé V, Brasseur L, et al. Intravenous lidocaine in central pain: A double-blind, placebocontrolled, psychophysical study. Neurology. Published online 2000. doi:10.1212/wnl.54.3.564

37. Kandil E, Melikman E, Adinoff B. Lidocaine Infusion: A Promising Therapeutic Approach for Chronic Pain. J Anesth Clin Res. 2017;08(01). doi:10.4 172/2155-6148.1000697

38. Thomson PD, Melmon KL, Richardson JA, et al. Lidocaine pharmacokinetics in advanced heart failure, liver disease, and renal failure in humans. Ann Intern Med. Published online 1973. doi:10.7326/000 3-4819-78-4-499

39. Bennett PN, Aarons LJ, Bending MR, Steiner JA, Rowland M. Pharmacokinetics of lidocaine and its deethylated metabolite: Dose and time dependency studies in man. J Pharmacokinet Biopharm. Published online 1982. doi:10.1007/BF01059261

40. Orlando R, Piccoli P, De Martin S, Padrini R, Floreani M, Palatini P. Cytochrome P450 1A2 is a major determinant of lidocaine metabolism in vivo: Effects of liver function. Clin Pharmacol Ther. Published online 2004. doi:10.1016/i.clpt.2003.09.007

41. Orlando R, Piccoli P, De Martin S, Padrini R, Palatini P. Effect of the CYP3A4 inhibitor erythromycin on the pharmacokinetics of lignocaine and its pharmacologically active metabolites in subjects with normal and impaired liver function. $\mathrm{Br} J$ Clin Pharmacol. Published online 2003. doi:10.1046/ j.1365-2125.2003.01718.x

42. Collinsworth KA, Strong JM, Atkinson AJ, Winkle RA, Perlroth F, Harrison DC. Pharmacokinetics and metabolism of lidocaine in patients with renal failure. Clin Pharmacol Ther. Published online 1975. doi:10.10 $\underline{02 / \operatorname{cpt} 197518159}$

43. Powell JR, Foster J, Patterson JH, Cross R, Wargin W. Effect of duration of lidocaine infusion and route of cimetidine administration on lidocaine pharmacokinetics. Clin Pharm. Published online 1986.

44. Pieper JA, Slaughter RL, Anderson GD, Wyman MG, Lalka D. Lidocaine clinical pharmacokinetics. Drug Intell Clin Pharm. 1982;16(4):291-294. doi:10.11 77/106002808201600403

45. Kim YC, Castañeda AM, Lee CS, Jin HS, Park KS, Moon JY. Efficacy and Safety of Lidocaine Infusion Treatment for Neuropathic Pain: A Randomized, Double-Blind, and Placebo-Controlled Study. Reg Anesth Pain Med. 2018;43(4):415-424. doi:10.1097/AA P.0000000000000741 
46. Moulin DE, Morley-Forster PK, Pirani Z, Rohfritsch C, Stitt L. Intravenous lidocaine in the management of chronic peripheral neuropathic pain: a randomized-controlled trial. Can J Anesth. 2019;66(7):820-827. doi:10.1007/s12630-019-01395-8

47. Heuvel DSASV, Wal DSEIV, Smedes LA, et al. Intravenous Lidocaine: Old-School Drug, New Purpose-Reduction of Intractable Pain in Patients with Chemotherapy Induced Peripheral Neuropathy. Pain Res Manag. 2017;2017. doi:10.1155/2017/805347 $\underline{4}$

48. Liu H, Lu F, Zhou D, et al. The Analgesic and Emotional Response to Intravenous Lidocaine Infusion in the Treatment of Postherpetic Neuralgia. Clin J Pain. 2018;34(11):1025-1031. doi:10.1097/AJP.0 $\underline{000000000000623}$

49. Przeklasa-Muszyńska A, Kocot-Kępska M, Dobrogowski J, Wiatr M, Mika J. Intravenous lidocaine infusions in a multidirectional model of treatment of neuropathic pain patients. Pharmacol Reports. 2016;68(5):1069-1075. doi:10.1016/j.pharep.2016.0 $\underline{6.010}$

50. Hutson $\mathrm{P}$, Backonja M, Knurr H. Intravenous lidocaine for neuropathic pain: A retrospective analysis of tolerability and efficacy. Pain Med (United States). 2015;16(3):531-536. doi:10.1111/pme.12642
51. Papapetrou P, Kumar AJ, Muppuri R, Chakrabortty S. Intravenous Lidocaine Infusion to Treat Chemotherapy-Induced Peripheral Neuropathy. A A case reports. 2015;5(9):154-155. doi:10.1213/XAA.000 0000000000197

52. Kajiume T, Sera Y, Nakano R, et al. Continuous intravenous infusion of ketamine and lidocaine as adjuvant analgesics in a 5-year-old patient with neuropathic cancer pain. J Palliat Med. 2012;15(6):719-722. doi:10.1089/jpm.2011.0097

53. Park CH, Jung SH, Han CG. Effect of intravenous lidocaine on the neuropathic pain of failed back surgery syndrome. Korean J Pain. 2012;25(2):94-98. d oi:10.3344/kjp.2012.25.2.94

54. Cousins MJ, Pickthorn K, Huang S, Critchley L, Bell G. The Safety and Efficacy of KAI-1678- An Inhibitor of Epsilon Protein Kinase C ( $\varepsilon$ PKC)-Versus Lidocaine and Placebo for the Treatment of Postherpetic Neuralgia: A Crossover Study Design. Pain Med (United States). 2013;14(4):533-540. doi:10.1 111/pme.12058

55. Tremont-Lukats IW, Hutson PR, Backonja MM. A randomized, double-masked, placebo-controlled pilot trial of extended IV lidocaine infusion for relief of ongoing neuropathic pain. Clin J Pain. 2006;22(3):266-271. doi:10.1097/01.ajp.0000169673.5 $\underline{7062.40}$ 